\title{
IPHONE R: EKSISTENSI MAHASISWA ILMU FALAK DALAM \\ MENANGGAPI PERBEDAAN AWAL BULAN KAMARIAH \\ (STUDI HUMANISTIC APPROACH)
}

\author{
Sadri Saputra \\ Fakultas Syariah dan Hukum \\ Universitas Islam Negeri Alauddin Makassar \\ Sadrisaputra8@gmail.com
}

\begin{abstract}
Abstrak
Tulisan ini mengkaji tentang eksistensi mahasiswa ilmu falak dalam merespon perbedaan awal bulan kamariah yang hamper setiap tahun terjadi di Indonesia. Problematikan penentuan awal bulan kamariah tersebut tidak terlepas dari peran mahasiswa ilmu falak dalam membangun sebuah pendekatan yang dapat menjadi bagian dari pemecahan probelama tersebut. Maka dari itu, penulis menawarkan sebuah konsep Inovasi Iphone $R$ (Inovasi Pemastian Hilal Satu Ramadhan) sebagai upaya dalam meningkatkan Eksistensi Mahasiswa Ilmu Falak dalam Penetapan Awal Bulan Kamariah. Inovasi ini dimaksudkan untuk memberikan wadah kepada mahasiswa Ilmu Falak secara khusus sebagai insan falak yang paham dan mengerti mengenai metode penentuan awal bulan kamariah kepada masyarakat secara umum, selain itu tentu inovasi ini menjadi wadah kepada mahasiswa ilmu falak dalam mengaktualisasikan ilmu pengetahuan yang telah didapatkan dalam bangku perkuliahan serta dalam mewujudkan Tri Dharma Perguruan Tinggi dalam hal pengabdian kepada masyarakat.
\end{abstract}

Kata kunci: Falak, hisab dan rukyat, iphone-R

\section{PENDAHULUAN}

Indonesia merupakan sebuah negara yang memiliki penduduk mayoritas Islam terbesar di dunia, hal ini menunjukkan bahwa kedudukan agama Islam sebagai Agama yang memiliki penganut terbesar di Indonesia tentu mendapat perhatian yang serius dari para pemeluknya. Sebuah fenomena tahunan yang sering kali kita saksikan dalam media nasional yang cukup kontroversial adalah penentuan awal bulan Ramadhan dalam kalender hijriah.

Berpuasalah kamu karena melihat hilal dan berbukalah kamu ketika melihat hilal pula; jika bulan terhalang oleh awan maka genapkanlah bilangan bulan Sya'ban tiga puluh hari. (HR. Bukhari, dan lafal diatas adalah lafalnya, 
dan juga diriwayatkan Muslim) ${ }^{1}$ Puasa ramadhan merupakan suatu ibadah yang wajib dilaksanakan oleh umat Islam, sebagaimana yang telah difirmankan Allah SWT dalam Al-Qur'an salah satunya "Wahai orang-orang yang beriman, diwajibkan atas kamu berpuasa sebagaiama diwajibkan atas orang sebelum kamu agar kamu bertakwa" (Q.S. Al- Baqarah: 183) ${ }^{2}$

Karena merupakan suatu ibadah wajib untuk dilaksanakan oleh umat Islam tentu dalam pelaksanaannya mendapatkan perhatian yang lebih dari umat Islam itu sendiri, sebagaimana yang telah kita ketahui bersama dalam penetapan awal bulan kamariah di Indonesia memiliki dua metode dengan berbagai kriteria masing-masing.

Metode hisab ${ }^{3}$ dan rukyat ${ }^{4}$ merupakan dua metode yang digunakan umat Islam di Indonesia dalam penetapan awal bulan kamariah, penetapan awal bulan kamariah dilaksanakan berdasar atas ijtihad para ulama dengan menggunakan salah satu dari kedua metode tersebut, sehingga sangat memungkinkan terjadi perbedaan-berbadaan pendapat di tengah-tengah masyarakat.

Permasalahan penentuan awal bulan kamariah harusnya tidak lagi menjadi suatu problematika tahunan umat Islam, sebab hisab dan rukyat hanyalah sebatas

\footnotetext{
${ }^{1}$ Al-Bukhari, Sahih Bukhari (Semarang: CV. Asy-Syifa', 1992/1413), II: 281, hadis no. 1909, "kitab as-Shaum" dari Abu Hurairah.

${ }^{2}$ Kementerian Agama Republik Indonesia, Al-Qur'an dan Terjemahannya (Surabaya: Halim, 2013).

${ }^{3}$ Hisab dalam bahasa arab berasal dari kata hasiba-yahsibu-hisaban-hisabatan, secara bahasa bermakna menghitung ('adda), kalkulasi (ahsa), dan mengukur (qaddara). Arwin Juli Rakhmadi Butar-Butar, Pengantar Ilmu Falak: Teori, Praktek, dan Fikih (Medan: Rajawali Pers, 2017), h. 70. Hisab menurut bahasa berarti hitungan, perhitungan, arithmetic (ilmu hitung), reckoning (perhitungan), calculus (hitung), computation (perhitungan), estimation (penilaian, perhitungan), appraisal (Penaksiran). Sakirman, "Kontroversi Hisab dan Rukyat Dalam Menetapkan Awal Bulan Hijriah di Indonesia,” Elfalaky Jurnal Ilmu Falak 1, no. 1 (2017): h. 2.

${ }^{4}$ Rukyat secara bahasa adalah melihat (an-nazr), berasal dari kata ra'a-yara-ra'yanru'yatan yang bermakna melihat dengan mata (bi al-'ain) dan atau melihat dengan ilmu (bi al'ilm). Hilal disebut demikian karena kemunculannya pada awal-awal malam bulan qamriyah. Arwin Juli Rakhmadi Butar-Butar, Pengantar Ilmu Falak: Teori, Praktek, dan Fikih (Medan: Rajawali Pers, 2017). Dari sudut pandang bahasa Indonesia, kata "rukyat", seperti halnya kata observation dalam bahasa Inggris, juga berasal dari kata asing, dari bahasa Arab, rukyat berasal dari kata jadian raay, yaraa, menjadi ra'yan, ru'yatan dan seterusnya. Dalam bahasa Arab, raay, sebagai kata kerja, berarti melihat atau mengamati. Rukyat, sebagaimana halnya observation, berarti juga pengamatan. Susiknan Azhari, Ilmu Falak; Perjumpaan Khazanah Islam dan Sains Modern (Yogyakarta: Suara Muhammadiyah, 2007), h. 113.
} 
metode bukan syari'at, oleh sebab itu tentu masyarakat diberikan kebebasan untuk memilih salah satu diantara kedua metode tersebut, karena metode hisab dan rukyat masing-masing memiliki landasan dalam Al-Qur'an dan Hadis.

Ilmu Falak merupakan salah satu disipilin ilmu yang membahas mengenai astronomi, secara umum ilmu falak bisa disamakan dengan Astronomi yakni salah satu ilmu yang mempelajari mengenai perbintangan, tetapi sebenarnya dalam konnsepnya ilmu falak merupakan sebuah ilmu yang mempelajari mengenai peredaran benda-benda langit, khususnya bumi, bulan dan matahari. Peredaran benda-benda langit tersebut digunakan untuk menentukan waktu sholat, arah kiblat, gerhana bulan dan matahari serta penentuan awal bulan hijriah, terkhusus mengenai penentuan awal bulan kamariah pada bulan hijriah, ilmu falak sebagai cabang ilmu yang memiliki peranan penting di dalamnya memberikan dua konsep metode dalam penetuan awal bulan kamariah.

Ilmu Falak juga dapat disebut ilmu astronomi karena di dalamnya membahas tentang bumi dan antariksa (kosmografi). Perhitungan-perhitungan dalam ilmu falak berkaitan dengan bendabenda langit. Walaupun hanya sebagian kecil dari benda-benda langit yang menjadi objek perhitungan karena secara etimologi astronomi berarti peraturan bintang-bintang "Law Of The Start" dan ilmu falak juga disebut dengan beberapa nama lain seperti: 1) Ilmu hisab karena melibatkan kegiatan perhitungan, 2) Ilmu rashd kerena membahas waktu-waktu tertentu, seperti waktu shalat, matahari tenggelam, malam, fajar, lewat tengah malam, dan sore, 4) Ilmu hisab rukyat karena dalam kegiatannya dilakukan dengan perhitungan (hisab) dan observasi (rukyat). ${ }^{5}$

Masalah hisab dan rukyat awal bulan kamariah merupakan salah satu masalah penting karena terkait dengan penentuan hari-hari besar umat Islam contohnya bulan Ramadhan, Syawal, dan Zulhijah. ${ }^{6}$ Bulan-bulan inilah yang

${ }^{5}$ Siti tatmainul Qulub, Ilmu Falak, (Jakarta : Raja Wali Pers, 2017) h.3.

${ }^{6}$ Diantara kedua belas bulan Hijriyah yang paling mendapat perhatian umat Islam adalah bulan Ramadhan, Syawal, dan Zulhijah, sebab didalamnya terdapat kewajiban berpuasa haji, hari raya dan haji atas umat Islam . lihat Q.S al Baqarah : 185 dan 197. Penetapan awal bulan hijriyah selain ketiga bulan tersebut dapat dipakai hisab. Karena dalam hal ini tidak diperlukan itsbat al Qadhi. Penetapan bulan ini semata-mata untuk perhitungan waktu, tidak benar-benar untuk kepentingan ibadah. Baca Imam Abu al -Hayan, al Bahr al muhith, Kairo : 
banyak menjadi sorotan umat muslim karena terdapat pelaksanaan ibadah wajib di dalamnya. Pada bulan Ramadan misalnya, yang menjadi penentuan hari pertama kewajiban puasa, dimana umat Islam melaksanakan puasa selama satu bulan dan diiringi dengan berbagai kegiatan ibadah lainnya untuk menambah keberkahan pada bulan suci ini.

Perbedaan dalam penentuan awal bulan kamariah khususnya awal Ramadhan menjadi sebuah fenomena yang sering terjadi di Indonesia. Perbedaan tersebut seringkali menimbulkan keresahan di kalangan umat Islam, mengganggu kekhusuan ibadah bahkan mengancam kemantapan ukhuwah. ${ }^{7}$

Perbedaan ini setidaknya berdampak pada integritas umat Islam di Indonesia. Padahal pemerintah sendiri dalam pelaksanaan sidang isbath telah melibatkan seluruh golongan maupun ormas Islam yang dinilai memiliki pengaruh di masyarakat. Meskipun demikian, dalam beberapa kasus perbedaan tersebut tidak juga dapat teratasi. ${ }^{8}$ Masing-masing ormas tersebut tetap saja mengeluarkan keputusannya.

Hal yang menjadi pemicu perbedaan pandangan dalam penetapan satu Ramadhan adalah begitu beragamnya metode-metode yang dipakai dalam menentukan awal bulan kamariah baik secara individu ataupun organisasi. Artinya di negara ini tidak ada aturan yang mengikat untuk mengikuti ketetapan pemerintah dalam hal ini diwakili oleh Kementrian Agama Republik Indonesia. Jadi, tidak ada larangan bagi setiap instansi maupun ahli yang menetapkan awal bulan kamariah menurut perhitungan kalender dan dasar hukum yang mereka terapkan. Sehingga wajar apabila sering dan banyak terjadi perbedaan penetapan. ${ }^{9}$

\section{Eksistensi Mahasiswa Ilmu Falak dalam Menanggapi Perbedaan Awal Bulan}

\section{Kamariah}

Beirut jilid II, hlm. 6 .

7 Sambutan Ketua Badan Hisab Rukyat Pusat, Drs. H. Wahyu Widiana, MA dalam buku Mennggagas Fiqih Astronomi karya Dr. T Djamaluddin 2005.

8 Susiknan Azhari, Hisab dan Rukyah (Wacana Untuk Membangun Kebersamaan di TengahPerbedaan), Yogyakarta: Pustaka Pelajar, cet I, 2003, hlm. 98.

9 Siti Kholisoh, Penentuan Awal Bulan Kamariyah menurut Tarekat Naqsabandiyah Khalidiyah Mujadadiyah Al-AliyahDusun Kapas DukuhKlopo Peterongan Jombang Jawa Timur. Skripsi Sarjana, Semarang: Fakultas Syariah IAIN Walisongo, 2012. 
Dengan adanya ilmu yang fokus untuk mempelajari hal mengenai hisab dan rukyat seharusnya tidak terjadi lagi perbedaan mengenai penetapan satu Ramadhan atau paling tidak masyakarakat sudah dapat saling menghargai satu sama lain tekrait metode yang masing-masing dianut oleh lembaga atau golongan tertentu. Masyarakat atau suatu Organisasi tertentu harusnya sudah memiliki pengetahuan mengenai penetapan awal bulan Ramadhan yang benar, tidak dengan mempertahankan berbagai macam metode dalam penetapan awal bulan kamariah yang biasanya di setiap daerah memiliki metode yang berbedabeda sesuai dengan budaya dan pemahamannya. Bahkan beberapa daerah, disamping memakai metode yang telah ditetapkan oleh lembaga yang bersangkutan, mereka memiliki metodenya sendiri sesuai dengan kepercayaan dan keyakinan dalam adat istiadat yang berlaku dalam daerah tertentu.

Untuk itu, dalam memecahkan permasalahan perbedaan pendapat mengenai penetapan awal Ramadhan diperlukan peran serta mahasiswa ilmu falak untuk turun serta dan menujukkan eksistensinya kepada masyarakat dalam memberikan pemahaman terkait dengan penentuan awal bulan kamariah khususnya awal bulan ramadhan dan syawal.

Dalam melakukan pendekatan dan mengefektifkan peran serta mahasiswa ilmu falak maka dibutuhkan sebuah inovasi yang mampu mendekati masyarakat dan memberikan pemahaman mengenai tata cara dan pedoman penetapan awal kamariah yang benar sesuai dengan landasan Al-Qur'an dan Hadis.

Inovasi ini harus menggunakan pendekatan khusus ke masyarakat sebab ini menyangkut perbedaan pemahaman yang berkaitan dengan pelaksanan ibadah pada bulan suci Ramadhan. Maka dari itu, penulis menawarkan sebuah konsep Inovasi Iphone $R$ (Inovasi Pemastian Hilal Satu Ramadhan) sebagai upaya dalam meningkatkan Eksistensi Mahasiswa Ilmu Falak dalam Penetapan Awal Bulan Kamariah.

Inovasi ini dimaksudkan untuk memberikan wadah kepada mahasiswa Ilmu Falak secara khusus sebagai insan falak yang paham dan mengerti mengenai metode penentuan awal bulan kamariah kepada masyarakat secara umum, selain itu tentu inovasi ini menjadi wadah kepada mahasiswa ilmu falak 
dalam mengaktualisasikan ilmu pengetahuan yang telah didapatkan dalam bangku perkuliahan serta dalam mewujudkan Tri Dharma Perguruan Tinggi dalam hal pengabdian kepada masyarakat.

Di samping itu, inovasi ini bertujuan untuk memberikan pemahaman kepada masyarakat umum khususnya pada berbagai daerah di Indonesia yang memiliki perbedaan pemahaman mengenai penetapan awal bulan kamariah khususnya awal bulan Ramadhan, sehingga diharapakan masyarakat luas dapat memahami bahwa terdapat dua metode dalam penentuan awal bulan kamariah yang populer di Indonesia yang masing-masing memiliki landasan dalam AlQur'an dan Hadis, keseragaman metode tentu sangat sulit untu terwujud namun, toleransi dan saling menghargai terhadap keyakinan setiap orang akan terwujud ketika masyarakat paham akan metode yang digunakan yang berdasar pada landasan Al-Qur'an dan hadis.

Inovasi Pemastian Hilal Satu Ramadhan atau yang selanjutnya di sebut dengan Iphone $R$ adalah salah satu inovasi yang bertujuan untuk meningkatkan peran mahasiswa Ilmu Falak dalam membantu masyarakat untuk mengatasi berbagai perbedaan pandangan mengani penetapan awal bulan kamariah khususnya awal bulan Ramadhan.

Konsep dari Iphone $R$ ini adalah dimana mahasiswa Ilmu Falak, sebagai insan falak yang memiki kompetensi mengenai meotde penetapan awal bulan kamariah, diharapakan dapat turun langusung ke masyarakat untuk memberikan pengetahuan secara intensif baik secara teori maupun praktik dengan terlebih dahulu menggunakan pendekatan humanistic approach kepada masyarakat.

Hal ini juga dapat membuat mahasiswa mewujudkan perannya sebagai Pengabdian kepada masyarakat karena dengan adanya inovasi ini tentu saja akan membuat masyarakat terbantu, khususnya bagi masyarakat awam yang sebelumnya belum mengetahui metode yang digunakan dalam penetapan awal bulan kamariah yang berlandaskan Al-Qur'an dan Hadis.

Tujuan pokok dengan adanya Iphone $R$ ini adalah untuk menghindari berbagai kesalahan dan perbedaan pandangan masyarakat mengenai penetapan awal bulan kamariah. Sehingga Iphone $R$ memiliki dua fokus utama, yang 
pertama yaitu untuk memperkanalkan Ilmu Falak kepada masyarakat baik itu teori dan praktiknya agar nantinya masyarakat paham sehingga tidak terdapat lagi perbedaan pemahaman di tengah-tengah masyarakat dan yang kedua adalah memberikan wadah bagi mahsiswa dalam meningkatkan peran dan Eksistensinya kepada Masyarakat sebagai bentuk pengabdian kepada masyarakat lewat pendekatan Humanistic Approach.

\section{Iphone R (Inovasi Pemastian Hilal Satu Ramadhan)}

Dalam penentuan awal bulan kamariah khusunya awal bulan ramadhan dapat menggunakan metode hisab dan metode rukyat, atau justru ada beberapa organisasi masyarakat yang menggunakan matode tersedirir, sehingga kesemua metode tersebut memiliki pengaruh yang sangat besar dalam penentuan awal bulan ramadhan. Organisasi masyarakat Islam yang ada di Indonesia saat ini memiliki pandangan yang berbeda-beda terhadap penggunaan metode hisab ataupun metode rukyat, sehingga hal ini mempengaruhi pelaksanaan awal bulan kamariah khususnya bulan ramadhan.

Seperti yang telah kita ketahui ada tiga organisasi besar Islam di Indonesia, seperti Muhammadiyah, Nadhatul Ulama (NU), dan Pemerintah masing-masing memilih salah satu dari metode hisab dan rukyat untuk dijadikan landasan dalam menetapkan awal bulan ramadhan.

Muhammadiyah dalam penetapan awal bulan ramadhan mengacu pada metode hisab hakiki, dimana dalam pelaksanaannya muhammadiyah melakukan perhitungan awal bulan ramadhan dengan memperhatikan teori-teori dan rumusrumus yang bersifat ilmiah dan terbaru. Sedangkan, Nahdhatul Ulama (NU) dalam penetapan awal bulan ramadhan mengacu pada metode rukyat, dimana dalam pelaksanannya dilakukan secara langsung mengamati hilal pada saat matahari terbenam diakhir tanggal hijrah pada bulan kamariah. Namun, berbeda dengan pemerintah, dalam penetapan awal bulan ramadhan pemerintah menggunakan kedua metode tersebut, dan disepakati melalui sidang isbat yang dilaksanakan oleh Kementerian Agama Republik Indonesia yang dihadiri langsung berbagai perwakilan tiap-tiap organisasi masyarakat Islam yang ada di Indonesia. 
Dari perbedaan metode yang digunakan oleh organisasi masyarakat Islam di Indonesia, telah tampak jelas bahwa metode hisab dan metode rukyat memiliki pengaruh yang sangat besar dalam penentuan awal bulan ramadhan yang pada akhirnya berdampak pada berbedanya waktu awal bulan ramadhan disetiap kalangan masayarakat Islam di Indonesia, oleh karena itu diharapkan peran serta Mahasiswa Ilmu Falak dalam memberikan pemahaman kepada masyarakat terkait dengan metode yang digunakan dalam penentuan awal bulan kamariah khusnya awal bulan ramdahan.

Ramadhan adalah salah satu bulan yang mulia karena kesuciannya. Banyak sekali ayat dan hadist yang menjelaskan mengenai tata cara untuk menetapkan awal dimulainya bulan yang penuh berkah ini. Salah satunya adalah potongan surah Al-Baqarah ayat 185:

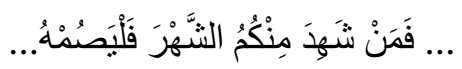

"Karena itu, barangsiapa di antara kamu menyaksikan (di negeri tempat tinggalnya) di bulan itu, maka hendaklah ia berpuasa pada bulan tersebut." (QS. Al Baqarah: 185) ${ }^{10}$

Sebagaimana dalam hadis Rasulullah SAW

Adapun dalam hadits adalah:

"Janganlah kamu berpuasa sebelum kamu melihat hilal (Ramadhan) dan janganlah kamu berbuka sebelum kamu melihat hilal (Syawal). Jika tertutup atas kalian maka takdirkanlah" (HR. Muslim dari Ibnu Umar) ${ }^{11}$

Dari Ibnu Umar r.a., ia berkata: Aku pernah mendengar Rasulallah Saw. bersabda: Bila kamu telah melihat tanggal satu bulan Ramadhan, maka puasalah, dan bila kamu melihat tanggal satu Syawal, maka berhari rayalah. Tetapi bila

\footnotetext{
Halim, 2013).

${ }^{10}$ Kementerian Agama Republik Indonesia, Al-Qur'an dan Terjemahannya (Surabaya:

${ }^{11}$ Muhyiddin Khazin, Ilmu Falak dalam Teori dan Praktik, Buana Pustaka, Yogyakarta, 2004, Hal. 148-149.
} 
terlihat mendung, maka perkirakanlah (sesuai dengan hari perhitunggan). (Hadits disepakati oleh Imam Bukhari dan Imam Muslim). ${ }^{12}$

Menurut mayoritas ulama, jika seorang yang ' $a d l$ (sholih) dan terpercaya melihat hilal Ramadhan, beritanya diterima. Dalilnya adalah hadits Ibnu 'Umar radhiyallahu 'anhuma,

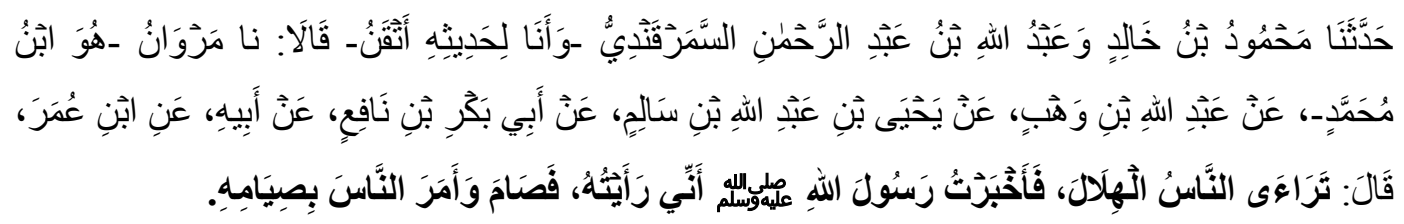

"Mahmud bin Khalid dan 'Abdullah bin 'Abdurrahman As-Samarqandi telah menceritakan kepada kami dan aku lebih pasti terhadap hadits 'Abdullah-, keduanya mengatakan: Marwan bin Muhammad menceritakan kepada kami, dari 'Abdullah bin Wahb, dari Yahya bin 'Abdullah bin Salim, dari Abu Bakr bin Nafi', dari ayahnya, dari Ibnu 'Umar, beliau berkata: Orang-orang berusaha melihat hilal, lalu aku kabarkan kepada Rasulullah shallallahu 'alaihi wa sallam bahwa aku telah melihatnya. Maka beliau pun puasa dan memerintahkan orang-orang untuk berpuasa" (HR. Abu Daud). ${ }^{13}$

Fenomena perbedaan pendapat mengenai penetapan awal bulan kamariah dapat menajdikan masyarakat tidak dapat menarik kesimpulan untuk mengikuti metode yang berlaku, sehingga masyarakat membutuhkan solusi yang dapat memastikan awal Ramadhan dengan menggunakan metode yang berdasar pada Al-Qur'an dan Hadis.

Iphone $R$ adalah salah satu solusinya. Iphone $R$ memanfaatkan kemampuan intelektual mahasiswa utamanya yang paham akan Ilmu Falak untuk turun langsung kepada masyarakat melakukan transfer knowledge baik itu secara teori dan praktek. Proses transfer knowledge yang dimaksudkan adalah bukan hanya sekedar mengadakan sosialisasi tetapi datang untuk menganalisis faktor-faktor yang menjadi penyebab perbedaan pandangan dan kemudian memberikan solusi, selain itu ketidakpahaman masyarakat terkait dengan

\footnotetext{
Hal. 312.

${ }^{12}$ Moh. Machfuddin Aladip, Terjemah Bulughul Maram, CV. Toha Putra, Semarang, 1985,

${ }^{13}$ HR. Abu Daud No. 2342. Syaikh Al Albani mengatakan bahwa hadits ini shahih.
} 
metode yang digunakan dalam penetapan awal bulan kamariah dapat terjawab di masyarakat karena kahadiran Mahasiswa Ilmu Falak di tengah-tengah masyarakat sebagai insan intelektual berkompetensi dalam bidang Ilmu Falak.

Solusi utama yang diberikan pada dasarnya adalah pemahaman mengenai pentingnya memahami metode yang diguakan dalam penetapan awal bulan kamariah yang benar agar masayarakat mampu menanggapi berbagai perbedaanperbedaan pandangan kedepannya. Setelah mengetahui hal tersebut, masyarakat kembali lagi dapat diajak untuk melakukan pengamatan secara langsung baik itu praktek langsung atau menggunakan media baik audio video maupun presentation, sebagai bentuk visualisasi dari teori yang disampaikan.

Hal ini harus di lakukan di daerah yang masyarakatnya memiliki keterbataasan akses untuk mendapatkan informasi mengenai penetapan awal bulan kamariah yang dilakukan oleh pemeritah. Masyarakat seperti ini masih kebanyakan menggunakan metode yang berpatokan pada budaya sehingga hasil hasil penetepannya juga akan berbeda-beda. Sehingga dengan korelasi ilmu dengan potensi mahasiswa dalam mewujudkan Iphone $R$ ini secara langsung dapat memberikan dampak untuk solusi perbedaan pendapat mengenai penetapan awal bulan Ramadhan yang selama ini masih banyak terjadi di Masyarakat, atau justru dapat menjadikan masyarakat lebih dewasa dalam menanggapai perbedaan yang ada, sebab kedua metode hisab dan rukyat tersebut masing-masing berlandaskan Al-Qur'an dan Hadis.

\section{Iphone R dengan Pendekatan Humanistic Approach}

Pendekatan adalah suatu upaya yang dilakukan seseorang agar orang lain melakukan sesuatu. Dalam tulisan ini pendekatan yang dimaksud adalah pendekatan dalam hal ilmu pengetahuan, dimana seseorang baik itu individu maupun kelompok melakukan suatu usaha mempengaruhi orang lain agar orang lain dapat mengetahui suatu ilmu pengetahuan. Pendekatan ini biasa dilakukan untuk mendekati suatu kelompok masyarakat dengan tujuan memberikan transfer ilmu kepada kelompok masyarakat tersebut.

Humanistic adalah sebuah teori belajar yang mengutamakan pada proses 
belajar bukan pada hasil belajar. Teori ini mengembang konsep untuk memanusiakan manusia sehingga manusia mampu memahami dan mengenali diri, lingkungan dan kepercayaannya. Teori ini lebih mengarahkan kepada pendekatan secara mendalam kepada setiap individu manusia.

Humanistic Approach adalah salah satu jenis pendekatan yang dilakukan dengan secara langsung dengan menjalin kedekatan kepada setiap individu agar memberikan kemudahan dalam melakukan transfer ilmu. Dalam konsep Iphone $R$ pendekatan ini sangat diperlukan, dimana mahasiswa sebelum melakukan transfer knowledge kepada masyarakat harus melakukan pendekatan pribadi terlebih dahulu. Sehingga dalam memberikan pemahaman mengenai pengetahuan mengani Ilmu Falak dalam hal ini adalah pemahaman yang berkaitan dengan metode penetapan awal bulan kamariah dan sebagainya dapat diterima dengan mudah.

\section{Kesimpulan}

Dengan adanya Pendekatan Humanistic Approach, akan memberikan kepercayaan kepada masyarakat untuk terbuka menerima berbagai pemahaman yang akan diberikan. Sehingga dengan kombinasi antara Iphone $R$ dan pendekatan Humanistic Approach ini dapat mengatasi perbeedaan pendapat di kalanagan masyarakat mengenai penetapan awal bulan kamariah khususnya awal bulan ramadhan dan syawal, selain itu dengan kolaborasi antara Iphone $\mathrm{R}$ dan Pendekatan Humanistic Approach ini dapat menjadi sebuah sistem transfer keilmuan yang efektif agar supaya dalam pemberian pemahaman kepada masyarakat, masyarakat dengan seksama dan terbuka dalam menerima ilmu yang diberikan, dengan adanya pengetahuan masyarakat terkait degan metode penetapan awal bulan kamariah tentu akan memberikan dampak kedewasaan berfikir bagi masyarakat dalam menyikapi perbedaan yang ada dalam penentuan awal bulan kamariah.

Dari kombinasi Iphone $R$ dan Pendekatan Humanistic Approach ini, tentu dapat tergambar secara jelas, bagaimana peran serta mahasiswa Ilmu Falak dalam menanggapi perbedaan pandangan masyararakat terkait dengan penentuan awal bulan kamariah, kehadirian mahasiswa sebagai garda terdepan dalam 
pengimplementasian Iphone $R$ dengan Pendekatan Humanistic Approach ini tentu akan memperlihatkan eksistensi Mahasiswa Ilmu Falak di tengah-tengah masyarakat luas dalam menyelesaikan perkara penentuan awal bulan kamariah di masyarakat.

\section{Daftar Pustaka}

Al-Bukhari, Sahih Bukhari II: 281, Hadis no. 1909, "Kitab As-Shaum” Dari Abu Hurairah. (Semarang: CV. Asy-Syifa', 1992/1413).

Arwin Juli Rakhmadi Butar-Butar, Pengantar Ilmu Falak: Teori, Praktek, dan Fikih (Medan: Rajawali Pers, 2017).

HR. Abu Daud no. 2342. Syaikh Al Albani mengatakan bahwa hadits ini shahih. Imam Abu al -Hayan, al Bahr al muhith, Kairo : Beirut jilid II.

Jawa Timur. Skripsi Sarjana, Semarang: Fakultas Syariah IAIN Walisongo, 2012, t.d.Syamsul Anwar, Hari Raya dan Problema Hisab-Rukyat. ( Yogyakarta: Suara Muhammadiyah, 2008)

Kementerian Agama Republik Indonesia, Al-Qur'an dan Terjemahannya (Surabaya: Halim, 2013).

Khalidiyah Mujadadiyah Al-Aliyah Dusun Kapas Dukuh Klopo Peterongan Jombang.

Moh. Machfuddin Aladip, Terjemah Bulughul Maram, (Semarang: CV. Toha Putra, 1985).

Muhyiddin Khazin, Ilmu Falak dalam Teori dan Praktik, (Yogyakarta: Buana Pustaka, 2004).

Sambutan Ketua badan Hisab Rukyat Pusat, Drs. H. Wahyu Widiana, MA dalam buku Menggagas Fiqih Astronomi karya Dr. T Djamaluddin 2005.

Sakirman, "Kontroversi Hisab dan Rukyat Dalam Menetapkan Awal Bulan Hijriah di Indonesia," Elfalaky Jurnal Ilmu Falak 1, No. 1 (2017).

Siti Kholisoh, Penentuan Awal Bulan Kamariyah menurut Tarekat Naqsabandiyah.

Siti Tatmainul Qulub, Ilmu Falak, (Jakarta: Raja Wali Pers, 2017).

Susiknan Azhari, Hisab dan Rukyah (Wacana Untuk Membangun Kebersamaan 
Elfalakĩy: Jüskial Ilmeñ Falak

di Tengah Perbedaan), (Yogyakarta: Pustaka Pelajar, cet I, 2003).

Susiknan Azhari, Ilmu Falak; Perjumpaan Khazanah Islam dan Sains Modern (Yogyakarta: Suara Muhammadiyah, 2007). 